\title{
Biological Management of Chrysanthemum Wilt (Fusarium oxysporum f.sp. chrysanthemi)
}

\author{
Alam Shamsher $^{1 *}$, S. K. Hasmi ${ }^{2}$, Mo. Alam Aftab ${ }^{3}$ and R. U. Khan ${ }^{2}$ \\ ${ }^{1}$ Department of Plant Pathology, Indira Gandhi Agricultural University, \\ Raipur 492012 (C.G.) India \\ ${ }^{2}$ Department of Plant Protection, Aligarh Muslim University, Aligarh 202002 (U.P.) India \\ ${ }^{3}$ Swami Keshwanand, Rajasthan Agriculture University, Bikaner (Rajasthan) India \\ *Corresponding author
}

\section{Keywords}

Fusarium oxysporumf.sp. chrysanthemi, Chrysanthemum, Trichoderma, bioagent

\section{Article Info}

Accepted:

15 May 2020

Available Online:

10 June 2020

\begin{abstract}
A B S T R A C T
Chrysanthemum flower (Chrysanthemum morifolium Ramat.) is popularly designated as

"Queen of the east", or autumn queen (as its bloom in November-December) (Shibata, 2008; Teixeira et al., 2013). In terms of global ornamental market value, its stands to the second position after rose. Vascular wilt caused by Fusarium oxysporum f. sp. chrysanthemi is one of the most devastating disease attacking all the growth stages from nursery to flowering(Pinto et al., 2010).Bio-efficacy of five bio-control agents namely Trichoderma harzianum, T. hamatum, T. viride, $T$. asperellum and $T$. virens were evaluated in-vitro against F.oxysporum f.sp. chrysanthemi, using dual culture technique on PDA and also pot condition. However, $T$. viride was found to be most effective antagonist in lab followed by T. harzianum, T.hamatum, T. virens and T. asperellum. Highest percent growth inhibition of pathogen recorded by $T$. viride $(69.53 \%)$ and $T$. harzianum $(63.60 \%)$. Meanwhile T. asperellum (36.33\%) showed least inhibition. Under greenhouse condition T. viride was found to be most effective and resulted the lowest disease severity $(32.0 \%)$ with highest inhibition(59.05\%) in compared to control, which was followed by $T$. harzianum, T. virens and T. hamatum. However, the soil treatment with T. asperellum was found to be least effective and resulted highest disease severity $(60.0 \%)$ of plants with lowest percent inhibition (29.04\%).
\end{abstract}

\section{Introduction}

Chrysanthemum is one of the most leading commercial floriculture crop, grown for cut and loose flowers throughout the globe. The word chrysanthemum is derived from the Greek words 'chrysos' and 'anthemon' or 'anthos' (flower) (Alam et al., 2020). This flower is botanically named as Chrysanthemum morifolium Ramat, which belongs to the family Asteraceae. In field the crop is challenged by a number of plant pathogens. Among all known pathogens, Fusarium oxysporum f. sp. chrysanthimi (Foc)causing wilt found to be the most destructive one in all growing regions 
including India (Singh et al., 2014). This facultative saprophyte can survive in soil up to six years in the absence of susceptible host, and can attack any growth stage of the plant(Pinto et al., 2010).It produces chlamydospores in harsh condition which helps in to withstand prevailing unfavorable environmental conditions (Singh et al., 2014, Booth 1971, Nash et al., 1961). Eradication of this pathogen is nearly impossible if once established in the field, due to multiple reasons, as; wide host range, saprophytic survival, resistant resting structures, break of resistance in newly developed resistant varieties, etc. At the same time, injudicious use of chemicals in farming activities is adding a great surplus to global threat of pollution. Hence, there is a strong need to adopt an ecofriendly approach to manage this threat. Therefore, the present investigation has been undertaken to figure out the best possible biocontrol agent against this devastating pathogen.

\section{Materials and Methods}

The present studies were carried out under laboratory and pot conditions at during kharif season of 2017-18, at Department of Plant Protection, Faculty of Agricultural Sciences, Aligarh Muslim University, Aligarh, Uttar Pradesh (India).

\section{Isolation and identification of the pathogen}

A survey was conducted during kharif season (2017-18) in nearby areas of Aligarh Muslim University. The diseased plant showing typical wilting symptoms were collected in polythene bags and brought to the laboratory for further isolation and identification of pathogen. Collected plantswere washed thoroughly under the running tap water to remove the adhering soil and debris. The root and basal stem were cut into small piece and rinsed in distilled water.
These pieces were surface sterilized with sodium hypochloride $(0.5-1.0 \%)$ followed by 2-3 washing with distilled water to remove excess of NaOCL. Two to three surface sterilized pieces were placed on solidified potato dextrose agar (PDA) poured in previously sterilized petri plates of $90 \mathrm{~mm}$ diameter, aseptically in laminar flow. The inoculated petri plates were further incubated in the Biological Oxygen Demand(BOD) incubator at $25 \pm 2^{\circ} \mathrm{C}$. These plates were further observed daily for fungal growth, if any, was repeatedly sub-cultured on PDA slants to obtain pure culture. Thereafter, isolated fungus was identified and confirmed on the basis of their cultural characteristics appeared in petri plates and morphological characteristics temporary slides under the compound microscope.

\section{Pathogenicity detection}

The pathogenic behavior of pathogen was tested in sterilized as well as unsterilized soil on local cultivar of chrysanthemum. The vegetative propagative material (rooted cuttings) was collected from local market and the inoculum of pathogen was prepared on Potato dextrose broth. Inoculation is done by cotton swab method on one-month old plants. The pathogen was re-isolate after 21 days of inoculation, from the inoculated plants.

Efficacy of Trichoderma spp. against $F$. oxysporum f. sp. chrysanthemi

\section{In-vitro}

Bio-efficacy of five different species of Trichoderma was evaluated in-vitro against pathogen. All the five species were provided by Department of Plant Protection, AMU (Aligarh). For identification of species, cultural and morphological studies were performed. Antagonistic activity of all Trichoderma was done against pathogen dual 
culture techniques (Chet et al., 1982; Bell et al., 1982). $5 \mathrm{~mm}$ disc of pathogen and bioagent were placed opposite to each other equidistantly from the periphery of $90 \mathrm{~mm}$ petri plate having solidified PDA. Petri plates were incubated in BOD incubator at $25 \pm 2^{\circ} \mathrm{C}$, until the petri plate with control treatment covered with the mycelial growth. All the treatments were replicated thrice. The percent inhibition was calculated by using formula given by Singh \& Vijay (2011) are as follows:

$\%$ inhibition over control $=\frac{\mathrm{C}-\mathrm{T}}{\mathrm{C}}$

$\mathrm{C}=$ Growth of fungus in the control Petri dishes.

$\mathrm{T}=$ Growth of fungus in the Dual Culture Petri dishes.

\section{Pot condition}

Reevaluation of all the prior tested Trichoderma spp. (tested in dual culture) was done in pot condition under green house. In this experiment plastic pots of $9 \mathrm{~cm}$ were filled with the mixture of well sterilized soil and FYM in the ration of 9:1 and 10 days old rooted suckers from nursery were planted in the pots. Inoculation was done when the suckers attain an age of 35 days. To inoculate healthy plants inoculum of pathogen (spore suspension of $10^{8} \mathrm{CFU}$ ) was applied at the basal part of plant @ $10 \mathrm{ml} / \mathrm{kg}$ of soil and then bio-agents were applied to the soil $10 \mathrm{~g} / \mathrm{kg}$ of soil one week after inoculation. Each replication was replicated thrice and watered daily. The observation of diseased plant showing yellowing, wilting mortality was recorded after 90 days of transplanting by using of disease severity scale ranging 0-5 (Lori et al., 2008).

\section{Disease scale}

Disease symptoms using a wilt severity index based on the scale,
$0=$ no symptoms, healthy plant;

$1=$ up to $25 \%$ light chlorotic foliage;

$2=25-50 \%$ light chlorotic foliage;

$3=$ severe chlorotic foliage plus up $10 \%$

necrotic leaves on $51-75 \%$ of the plant;

$4=$ necrotic foliage on $11-50 \%$ of the plant;

$5=$ dead plant

percentdiseaseindex $=\frac{\text { Sum of all disease rating }}{\text { Total number of rating } X \text { Maximum disease grade }} X 100$

$\%$ inhibition $=\quad \frac{\mathrm{c}-\mathrm{T}}{\mathrm{c}} \times 100$

Where,

$\mathrm{C}=$ control plant.

$\mathrm{T}=$ Treatment plant.

\section{Results and Discussion}

\section{In-vitro (in dual culture test)}

Bio-efficacy of five bio-control agents namely Trichoderma harzianum, T. hamatum, $T$. viride, $T$. asperellum and $T$. virens were evaluated in-vitro against Fusarium oxysporum f.sp. chrysanthemi, using dual culture technique on PDA. The observations, thus, recorded on radial growth of antagonists and test fungus is represented in fig. 1. It is evident from the observations that all biocontrol agents significantly inhibited the radial growth of pathogen in compared to control. However, T. viride was found to be most effective antagonist followed by $T$. harzianum, T.hamatum, $T$. virens and $T$. asperellum resulted in $21 \mathrm{~mm}, 24 \mathrm{~mm}, 29$ $\mathrm{mm}, 32.33 \mathrm{~mm}$ and $35 \mathrm{~mm}$ growth of the test pathogen, respectively. Highest percent growth inhibition of pathogen recorded by $T$. viride $(69.53 \%)$ and T. harzianum $(63.60 \%)$ (fig. 1). Meanwhile T. asperellum $(36.33 \%)$ showed least inhibition. Interestingly, the bioefficacy of all these antagonists varied significantly in radial growth inhibition in of F. oxysporum f.sp.chrysanthemi. 


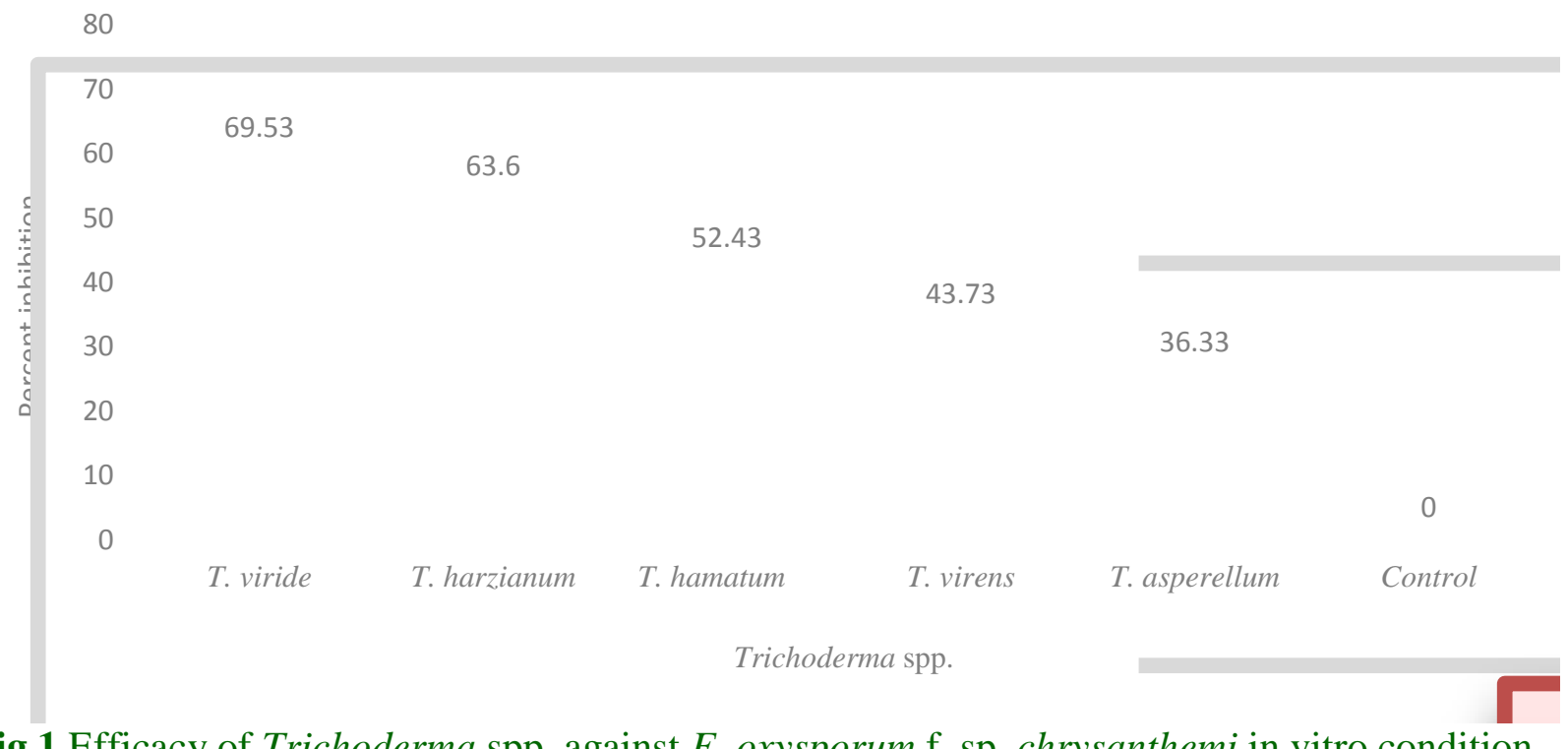

Fig.1 Efficacy of Trichoderma spp. against $F$. oxysporum f. sp. chrysanthemi in vitro condition

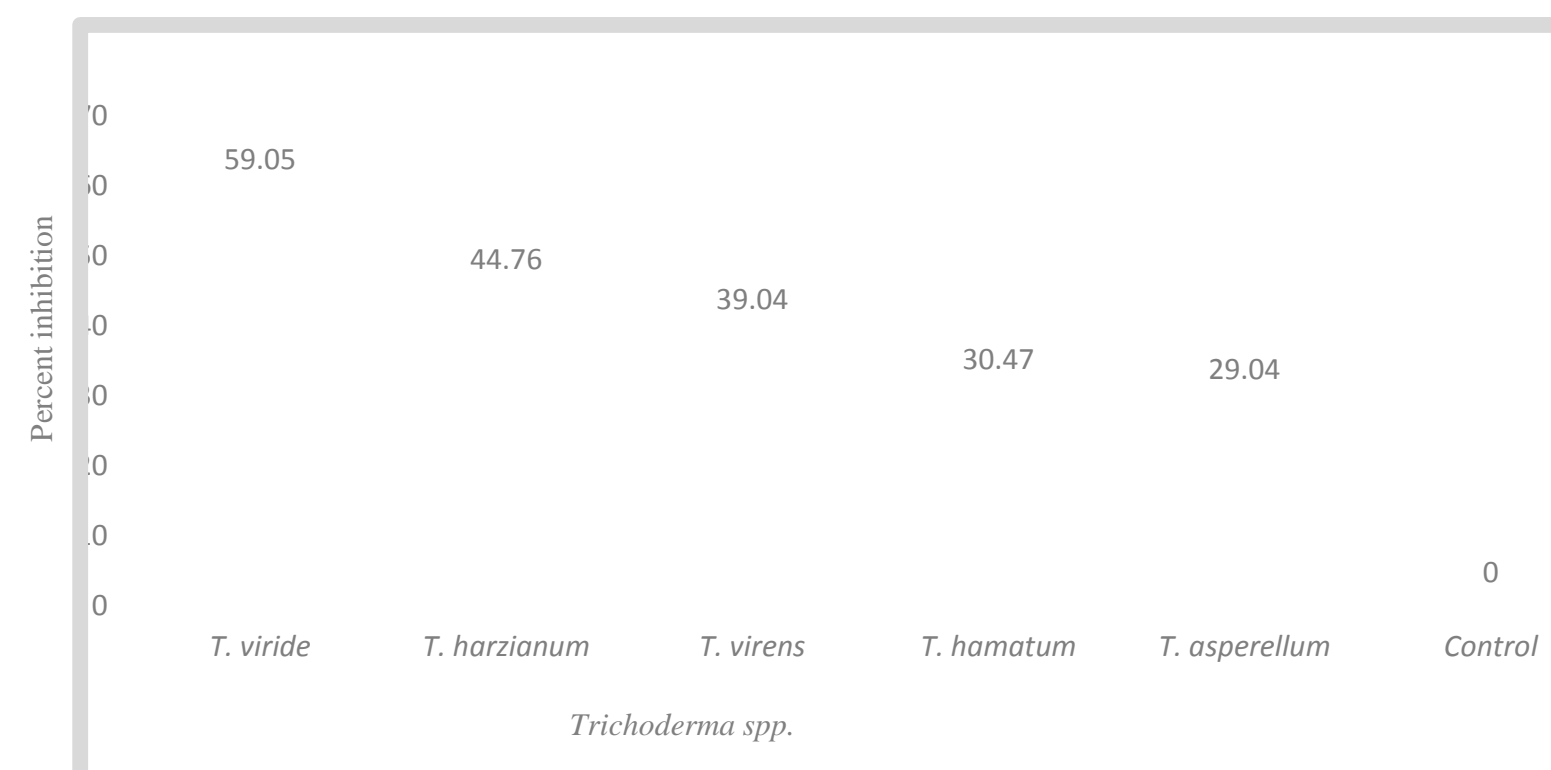

Fig.2 Efficacy of Trichoderma spp. against $F$. oxysporum f. sp. chrysanthemi in pot condition

\section{Pot condition}

Bio-efficacy of five Trichoderma sp. namely T. harzianum, T. viride, T. asperellum, $T$. virens and T. hamatum, were also evaluated in pots under greenhouse condition. All the Trichoderma spp. were applied in soil after one week of pathogen inoculation. A similar effectiveness of $T$. viride was recorded in term of reduced disease severity $(32.0 \%)$ with highest inhibition (59.05\%), i.e., lowest among all the tested species, which was followed by $T$. harzianum, T. virens and $T$. hamatum. However, the soil treatment with T. asperellum was found to be least effective and resulted highest disease severity $(60.0 \%)$ of plants with lowest percent inhibition (29.04\%) (Fig. 2). 
The present investigation, thus, suggests the antagonistic potential of Trichoderma spp. which could be exploited further for the management of $F$. oxysporum f. $\mathrm{sp}$. chrysanthemi. Although, efficacy of Trichoderma spp. has earlier been reported against $F$. oxysporum by several other workers under in-vitro condition. Singh \& Vijay (2011)were evaluated seven isolates of T. harzianum (Th) namely $\mathrm{T} 1, \mathrm{~T} 2, \mathrm{~T} 3, \mathrm{~T} 4, \mathrm{~T} 5$, T6 and T7 against $F$. oxysporumf. sp. chrysanthemi. The isolates effectively inhibited the mycelial growth of pathogen and recorded maximum inhibition with $\mathrm{T} 3$ isolate i.e. 66.0\%.Bahatnagar H. (1986) were evaluated antagonist Trichoderma harzianum, $T$. coningi and $T$. viride were highly antagonistic to $F$. udum under in vitro. S. Sundaramoorthy and P. Balabaskar (2013) reported that ANR-1 inhibited the mycelial growth of $F$. oxysporum f. sp. lycopersici to an extent of 53.00 per cent over control. This was followed by KGI-3 (38.12\%), RTM-5 6 (31.11\%) and KPI-9 (27.22\%).

The efficacy of Trichoderma spp. had earlier been also reported against Fusarium oxysporum under pot condition by Singh \& Kumar (2011)Among the 3 isolates maximum disease control was recorded with T3 $(91.0 \%)$ and minimum with T5 (81\%). Disease control provided by $\mathrm{T} 3$ isolate was significantly higher among all the Trichoderma isolates, Locke et al., (1985) a wild-type isolate of Trichoderma viride (T-1) and a benomylresistant biotype (T-I-R9), alone or in combination with Aspergillus ochraceus, reduced disease by at least $50 \%$ in vegetatively maintained plants. (Sivan et al., 1984). Sivan and Chet (1986) reported that $T$. harzianum successfully controlled Fusarium spp. in cotton, wheat and musk melon in naturally infected soil. Muhukumar et al., (2005), and Nikam et al., (2007) also found Trichoderma spp. as a potential bio-control agents of $F$. oxysporum on various crops.
It is clear from the foregoing discussion that Tricoderma spp. is a good candidate for biological control due to the different modes of action the fungus employs in inhibiting the growth of $F$. oxysporum f. sp. chrysanthemi. The present evaluation thus gave clear indication that the $T$. viride and $T$. harzianum are strong and virulent antagonists, which can be effectively used in the management of chrysanthemum wilt. Combination of seedling dip and soil application appears to be most effective.

\section{References}

Alam, S.,Hasmi, S.K., \& Khan, R.U., (2020). Effect of nutrient media on radial growth of Fusarium oxysporum f. sp. chrysanthemi.International Journal of Chemical Studies, 8(1): 101-103.

Anonymous (2013) Indian Horticulture Database. NHB, Ministry of Agriculture, Government of India.

Bahatnagar H. 1986. Influence of environmental condition on antagonistic activity of Trichoderma spp. against Fusarium udum. Indian Journal of Mycology and Plant Pathology. 26: 5863

Booth C. 1971 - The Genus Fusarium. CMI, Egham, Surrey, U. K. 143 pp.

Chet I., 1987. Trichoderma application, mode of action, and potential as a biocontrol agent of soil-borne plant pathogenic fungi. In: Chet I. (ed). Innovative Approaches to Plant Disease Control, pp. 137-160. John Wiley and Sons, NY, USA.

Hsieh SPY. 1985 - Ecology and control of gladiolus Fusarium wilt. Plant Prot. Bull. Taiwan 27 (3), 247-256.

Li, P., Chen, J., Li, Y., Zhang, K., \& Wang, H. (2017). Possible mechanisms of control of Fusarium wilt of cut chrysanthemum by Phanerochaete chrysosporium in continuous cropping 
fields: A case study. Scientific reports, 7(1), 15994.

Locke, J. C., Marois, J. J., \&Papavizas, G. C. (1985). Biological control of Fusarium wilt of greenhouse-grown chrysanthemums. Plant disease (USA).

Lori, G. A., Wolcan, S. M., \&Larran, S. (2008). Fusarium yellows of celery caused by Fusarium oxysporum f. sp. Apii in Argentina. Journal of Plant Pathology, 173-178.

Muthukumar, A., Karthikeyan, G., \&Prabakar, K. (2005). Biological control of tuber rot (Fusarium oxysporum) tube rose (Polianthes tuberosa L.). Madras Agric. J,92(1012), 742-744.

Nash SM, Christou T, Snyder WC. 1961 Existence of Fusarium solani f. sp.cucurbitae and $F$. solani f. sp.phaseoli in soil. Phytopathology 55, 963-966.

Nikam, P. S., Jagtap, G. P., \&Sontakke, P. L. (2007). Management of chickpea wilt caused byFusarium oxysporium f. sp. ciceri. African Journal of Agricultural Research, 2(12), 692-697.

Pinto, Z. V., Morandi, M. A. B., \&Bettiol, W. (2013). Induction of suppressiveness to Fusarium wilt of chrysanthemum with composted sewage sludge. Tropical Plant Pathology, 38(5), 414-422.

S. Sundaramoorthy and P. Balabaskar (2013). Biocontrol efficacy of Trichoderma spp. against wilt of tomato caused by Fusarium oxysporum f. sp. lycopersici.
Journal of Applied Biology \& Biotechnology, 1(03), 036-040.

Shibata, M. (2008). Importance of genetic transformation in ornamental plant breeding. Plant biotechnology, 25(1), 38.

Singh, P. K., \& Kumar, V. (2014). Fusarium wilt of chrysanthemum-problems and prospects. Plant Pathology \& Quarantine, 4(1), 33-42.

Singh, P. K., \& Vijay, K. (2011). Biological control of Fusarium wilt of Chrysanthemum with Trichoderma and botanicals. Journal of Agricultural Technology, 7(6), 1603-1613.

Sivan, A. and Chet, I. (1986). Biological control of Fusarium spp. in cotton, Wheat and Muskmelon by Trichoderma harzianum. Phytopathology, 116: 39-47.

Sivan, A., Elad, Y. and Chet, I. (1984). Biological control effects of a new isolate of Trichoderma harzianum on Pythium aphanidermatum. Phytopathology, 74: 498-501.

Teixeira da Silva, J. A., Shinoyama, H., Aida, R., Matsushita, Y., Raj, S. K., \& Chen, F. (2013). Chrysanthemum biotechnology: Quo vadis?.Critical reviews in plant sciences, 32(1), 21-52.

Xia, Y., Deng, X., Zhou, P., Shima, K., \& Teixeira da Silva, J. A. (2006). The World floriculture industry: dynamics of production and markets. Floriculture, Ornamental and Plant Biotechnology, Adv. Trop Issues, 4, 336-347.

\section{How to cite this article:}

Alam Shamsher, S. K. Hasmi, Mo. Alam Aftab and Khan. R. U. 2020. Biological Management of Chrysanthemum Wilt (Fusarium oxysporum f.sp. chrysanthemi). Int.J.Curr.Microbiol.App.Sci. 9(06): 639-644. doi: https://doi.org/10.20546/ijcmas.2020.906.081 